\title{
WATER QUALITY OF LAKE EŁK AS A FACTOR CONNECTED WITH TOURISM, LEISURE AND RECREATION ON AN URBAN AREA
}

\author{
Renata Tandyrak, Katarzyna Parszuto, Jolanta Grochowska \\ Department of Water Protection Engineering, University of Warmia nad Mazury in Olsztyn, Poland
}

Manuscript received: March 18, 2016

Revised version: August 11, 2016

Tandyrak R., Parszuto K., GrochowsKa J., 2016. Water quality of Lake Ełk as a factor connected with tourism, leisure and recreation on an urban area. Quaestiones Geographicae 35(3), Bogucki Wydawnictwo Naukowe, Poznań, pp. 51-59, 4 figs, 3 tables.

AвSTRACT: Lake Ełk as an important element of the urban landscape is associated with tourism and active recreation and because of it with the economy of the town. Since 1999 the renovation method with the use of artificial aeration with simultaneous phosphorus inactivation and also as a biological filter - BIO-HYDRO structures were applied on the lake. This process was lasting 10 years and brought only a short-term improvement. At the same time, the shores of the lake were managed to develop of lake tourism: beach, swimming pool, tennis courts, a promenade, and two a water equipment rentals. The illuminated fountain, the road bridge and well - developed catering - accommodation base were made as well.

KEY WORDS: urban lake, lake tourism, pollution, restoration

Corresponding author: Renata Tandyrak (e-mail: renatat@uwm.edu.pl)

\section{Introduction}

Lake is one of the most important city-creating factors. Locating cities nearby lakes and rivers, not only supplies the town with water, generates the energy and make transport easier, but over the years it has also allowed the sewage disposal (Britton et al. 1975). In the space, which is dominated by asphalt and concrete surfaces, lakes prevent monotony and diversify environment, shape the local microclimate and play an important role in leisure and active recreation of the town's inhabitants (Martinez-Arroyo, Jauregui 2000, Naselli-Flores et al. 2007, Tandyrak et al. 2015). Stagnating water creates a plane of the composition, which reflects the environment, increases the spaces optically and introduces a variety in the structure of the city (Bartosiewicz 1998).

Such kind of neighborhood can be difficult for the lake because water pollution can be related to human activities in a large extent. Surface flows from urbanized areas bring a number of chemical impurities that among rain water and municipal and industrial sewage contribute to the deterioration of environmental (Kistowski 1996, Birch, McCaskie 1999, Tuszyńska 2006). A common practice in arranging sites on the shores of lakes is a direction of concreted and asphalted paths towards the lake (Lossow 1997).

Typical urban lakes and lakes, which catchment's area is partly urbanized are an important resource for tourism and recreation. The concept 
of leisure is an interdisciplinary issue and difficult to define, although widely used (Kwilecki 2011, Cosgrove, Jackson 2015). Since its amount and way of use depends the quality of life (daily comfort, health, work performed). One of the ways of using leisure time is tourism, which is understood as journeys carried on for leisure, entertainment and new experiences. A similar function meets the recreation, but it does not have to be associated with a change of residence (Kuś et al. 1981).

On the other hand, these activities although they are desirable and bring income, are a form of anthropogenic influence on a lake (Curtis 2003). Throughout the world lakes are often used as a form of promotion and the basis for shaping the city's image (Yamamoto, Nakamura 2004, David et al. 2007). Nevertheless, as DudaGromada (2009) noted, there are few studies on the meaning and importance of the lake in tourism. They usually appear as the background for the research on other issues, e.g. water sports, planning and promoting the development of tourism, or pollution and changes in the lake or urban ecosystem.

The functioning of a lake is complementary to the tasks set out for the city. In the case of Ełk, the largest and the most populous city in Mazury area, local government authority's focus was placed on the development and operation of tourism. To allow both residents and tourists an active recreation in the industrialized area, at the beginning of the $90 \mathrm{~s}$ in the $20^{\text {th }}$ century the city has acceded to the strategy of Polish Green Lungs, which purpose was the management based on the idea of sustainable development. These concern not only the management of the lake, but in fact the whole of its catchment (DudaGromada 2009). Because lake ecosystems are extremely sensitive and vulnerable to the effects of increasing pollution loads from strongly transformed basin (Schueler and Simpson 2001), local authorities began the modernization of the sewage treatment plant as well as Lake Ełk renovation. It was supposed to improve the lake water quality, comfort and aesthetics of life in the city and to bring the added effect of restoring the recreational function of the reservoir.

This work was aimed at proving that the quality of the lake water is a basic factor to leisure and recreation in the city. The protection and care for the quality of the waters of Lake Ełk promote lake tourism covering all forms of tourism-recreational activity undertaken both on water and on land.

\section{Material and methods}

This paper summarizes the results achieved by Lossow and Gawrońska (1992) when designing the restoration method of Lake Ełk, detailed data from the years 1999-2008 received in the Hydrobiological Station Centre for Ecological Research in Mikołajki (Wielgat 2009), and the data from 2011 year published by Regional Inspectorate for Environmental Protection in Olsztyn (WIOŚ 2012), including the following parameters: visibility of Secchi disc (SD), electrolytic conductivity, the chlorophyll a concentration, total (TN) and mineral (N-NH $\mathrm{NO}_{4}$ ) nitrogen, total phosphorus (TP) and mineral ( $\left.\mathrm{PO}_{4}\right)$ and our own research.

Our study was carried out during the vegetation period in 2015 and 2016 years. Water samples for investigation were collected with the use of Ruttner apparatus during the summer stagnation in the northern part of Lake Ełk from the surface layer $(1 \mathrm{~m})$, hypolimnion layer $\left(\mathrm{PO}_{4}\right)$ and near bottom layer $\left(\mathrm{N}-\mathrm{NH}_{4}\right)$ - analogously as in previous years. Determination of these mineral forms of nutrients in the deep parts of the lake water is important, because they supply trophogenic layer of lake during the circulation period.

Analyses were carried out according to the common methodology of hydrochemical research (Hermanowicz et al. 1999). Colorimetric measurements: total phosphorus (TP) and phosphate $\left(\mathrm{PO}_{4}\right)$, were measured using a NANOCOLOR spectrophotometer, ammonia $\left(\mathrm{NH}_{4}-\mathrm{N}\right)$ amounts were determined on a Merck SQ118 spectrophotometer. TN was measured with the use of the HACH IL TOC - TN analyser. $\mathrm{PO}_{4}$ were determined using ammonium molybdate (VI) and $\mathrm{SnCl}_{2}(\lambda=690 \mathrm{~nm})$. Chlorophyll a (Chl a) by colorimetric method after concentration on a Whatman GF/C glass-fiber filter and extraction with acetone $(\lambda=650$ and $750 \mathrm{~nm})$.

Sub-catchment's areas (according to the shape and way of land use) were determined by plannimetring their surfaces using the tools available 
on geoportal.pl site (Geoportal, 2016). Shores of lake and the surrounding area development were characterized on the basis of our observation in 2015-2016 years. Surface flow of nutrients was calculated with the use of coefficients given by Giercuszkiewicz-Bajtlik (1990). A dangerous load of pollution was calculated according to hydrological model of Vollenweider (1976).

The trophic state index (TSI) was determined using the logarithmic transformation of visibility (SD), the concentration of chlorophyll a (Chl a), total phosphorus (TP) (Carlson 1977) and total nitrogen (TN) (Kratzer, Brezonik 1981). TSI allows determining the fertility of the lake, which is directly connected with the occurrence of algal blooms (and chlorophyll a content in algae) and consequently, the transparency of the water (SD). The presence of algal blooms, especially cyanobacteria, periodically eliminates a bathing function of reservoir because of the toxic metabolic products of these organisms released into the water (Codd 1995, Tandyrak et al. 2016). The presence of cyanobacterial is related to the ratio of TN/TP, the high value of this ratio is favourable, indicating the disappearance of cyanobacterial blooms and the growth of more desirable species.

\section{Characteristics of the study area}

Lake Ełk $\left(53^{\circ} 48^{\prime} 24^{\prime \prime} \mathrm{N} 22^{\circ} 20^{\prime} 58^{\prime \prime} \mathrm{E}\right)$ is located in the central part of Ełk Lakeland (Mazury, NE Poland). The administrative boundaries of the city are part of the municipality of Ełk. Shape of the lake bowl allows distinguishing three morphometrically different sections: northern part (80.4 ha, maximum depth $24 \mathrm{~m}$ ) is clearly separated by an artificial embankment with the road bridge and it is connected to the rest of the lake by a narrow isthmus, the middle part (185.5 ha, maximum depth $-55.8 \mathrm{~m}$ ) with the most varied morphometry and western part of lake (116. 6 ha, maximum depth $-11.7 \mathrm{~m}$ ), which is separated by a narrowing with shallow water. Basic morphometric data are summarized in Table 1 . The reservoir (area 382.4 ha, mean depth $15 \mathrm{~m}$ ) has an inflow - River Ełk inflows on the east side of the middle part of lake and it outflows from the south-western part (Fig. 1). The coastline of lake is well developed (shoreline development 2.69)
Lake Ełk is connected to the Lake Sunowo in the west and Szarek and Barany in the south.

The shores of the lake are varied, generally low, but high and steep in some places. They are surrounded by buildings, roads, fields and meadows. Lake's northern and central parts are moderately covered by macrophytes, the southern part is covered abundantly. The reservoir is inhabited by fish species typical for eutrophic lakes (crucian carp, tench, bream, roach, pikeperch, whitefish, pike and eel) and used for fishing (information communicated by fishermen, 2015).

The direct catchment of Lake Ełk occupies 309.7 hectares. Urban structures share 33.3\% (117.5 ha), arable land covers $31.4 \%$ (98.9 ha), forests $16.6 \%$ (52.3 ha), horticulture $-9.7 \%$ (30.6 ha), and post-agricultural areas with a large share of spontaneous vegetation $-3.3 \%$ (10.4 ha) (Fig. 2). The average slope of the basin is $1.3 \%$.

Surface supply of Lake Ełk from the catchment

The reservoir is supplied with the water of the River Ełk in the middle part of the lake, the small watercourse in the north, tributaries from the lakes, numerous drainage ditches and surface runoff. The rainy sewage is also discharged to the lake. For many years the lake was the receiver of municipal and industrial sewage of Ełk town $\left(20,000 \mathrm{~m}^{3} \mathrm{~d}^{-1}\right)$ which were subjected to mechanical treatment only. It was also a disposal site of the wood before it industrial processing. Since 1976 the northern part of the lake has begun to receive waters from the trout fish farm.

According to Lossow and Gawrońska (1992), in the early 90's, nutrients load delivered with River Ełk and from housing estates without sewage system was significant: $5.49 \mathrm{~g} \mathrm{TP} \mathrm{m}^{-2} \mathrm{yr}^{-1}$ and $62.24 \mathrm{~g} \mathrm{TN} \mathrm{m}^{-2} \mathrm{yr}^{-1}$ and by Vollenweider (1976) it exceeded critical load 2.5 times.

Table 1. Morphometric parameters of Lake Ełk (Jańczak 1999).

\begin{tabular}{|l|c|}
\hline \multicolumn{1}{|c|}{ Parameter [unit] } & Value \\
\hline Altitude [m a.s.l.] & 120.0 \\
\hline Water surface area [ha] & 382.4 \\
\hline Volume [m ${ }^{3}$ ] & 57420300 \\
\hline Maximum depth [m] & 55.8 \\
\hline Average depth [m] & 15.0 \\
\hline Maximum length [m] & 4000 \\
\hline Maximum width [m] & 3500 \\
\hline Shoreline length of the bowl [m] & 18650 \\
\hline Shoreline development & 2.69 \\
\hline
\end{tabular}




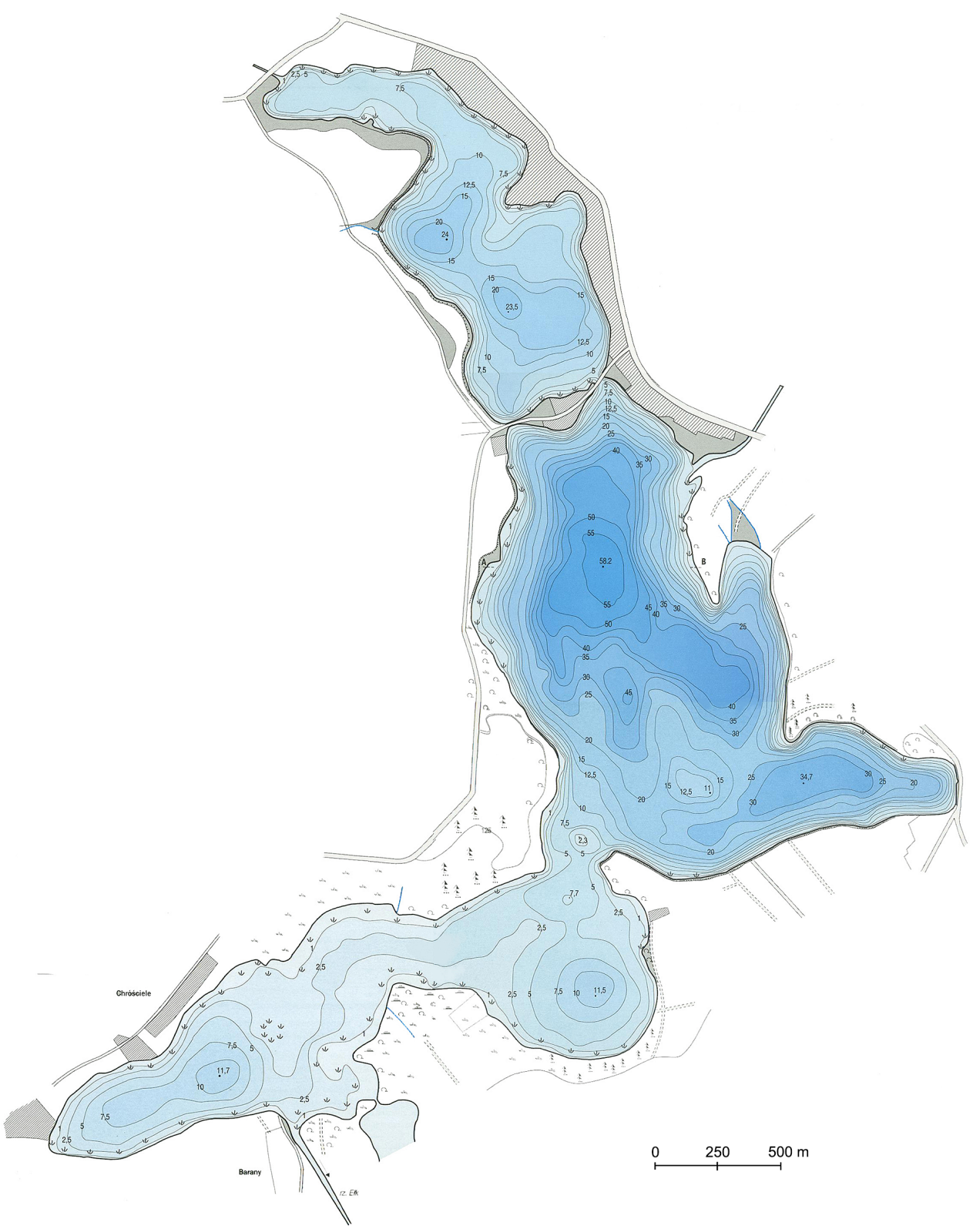

Fig. 1. Bathymetric plan of Lake Ełk (Regional Inspectorate for Environmental Protection 2012).

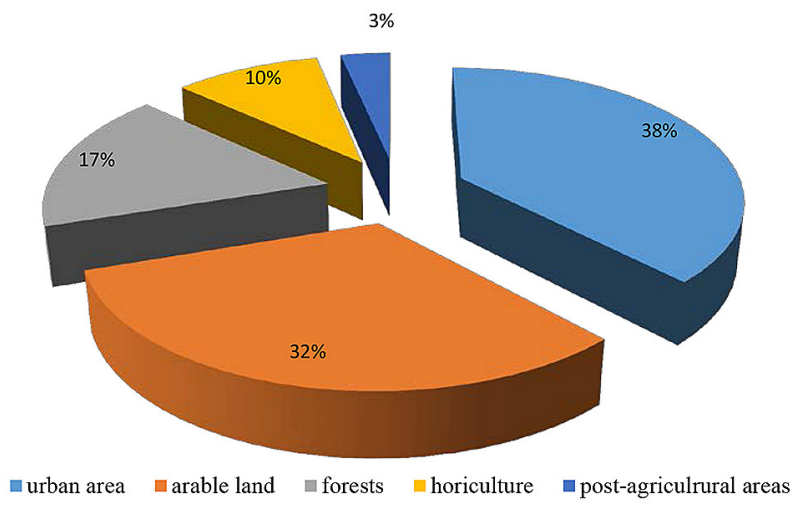

Fig. 2. The use of land (\%) in the catchment of Lake Ełk (2015).
Estimating the current surface (areal) inflow from the catchment and considering the kind of its management and using factors recommended by the OECD for flat areas (GiercuszkiewiczBajtlik 1990) we calculated $2074.7 \mathrm{~kg} \mathrm{~N} \mathrm{yr}^{-1}$ and $155 \mathrm{~kg} \mathrm{P} \mathrm{yr}^{-1}$ (respectively, calculated on surface of the lake: $5.42 \mathrm{~g} \mathrm{~N} \mathrm{~m}^{-2} \mathrm{yr}^{-1}$ and $0.41 \mathrm{~g} \mathrm{P} \mathrm{m}^{-2} \mathrm{yr}^{-1}$ ). This calculation does not account the load inflows with the paths and river. According to the hydrological model of Vollenweider (1976) the permissible load for Lake Ełk is $1.08 \mathrm{~g} \mathrm{P} \mathrm{m}^{-2} \mathrm{yr}^{-1}$, and critical one is $2.15 \mathrm{~g} \mathrm{P} \mathrm{m}^{-2} \mathrm{yr}^{-1}$. 


\section{Lake Ełk restoration}

According to the Guidelines of Basic Lakes Monitoring (Kudelska et al. 1992), each part of the Lake Ełk demonstrates different degrees of susceptibility to degradation: the western part is the least resistant (IV category of susceptibility), the centre one demonstrates the best morphometric properties (I category), and northern part is characterized by average conditions (II category). However, since the 70s of the last century, this part of the lake was subjected to accelerated eutrophication because of a pollution load.

Metalimnion zone water was anoxic, what had led to the production of hydrogen sulphide and an increasing the internal phosphorus loading. The quality of water in the lake qualified it to the eutrophic state and blue-green algae made it difficult to use in recreational and economic way Therefore, in 1999 the restoration treatment was implemented in this part of the lake. The concept drawn by Lossow and Gawrońska (1992), in which to carry out the aeration with the full destratification, was proposed. Finally, in practice, the treatment without damaging the thermal stratification was made.

Two devices of Stratiflox 1000 (located at the deepest parts of northern part of the lake) were used. At the same time coagulant PIX was dozed into the hypolimnion water (near the aerator's nozzles). These devices were working as destratificators during the periods of circulation. To the lake water $7000 \mathrm{~m}^{3}$ of air per day was introduced, while the coagulant demand on the basis of current analysis of the concentration of phosphorus was calculated at $46704 \mathrm{~kg} \mathrm{45 \%}$ PIX (Lossow, Gawrońska 1992).

The renovation was supported with BIOHYDRO structures (Bańkowska 2008). Near the inflow origined to the fish farm to the lake water 300 pcs. structures were set. They were supposed to be the basement for periphyton algae development and to act as biological filter. Their effects are summarized in Table 2. This method is undoubtedly less invasive than chemical phosphorus precipitation and so in the opinion of the lake' users-residents and tourists - it is natural, especially you can also observe birds stopping at the structures. Łągiewka (1994) indicates its high potential in water purification and water treatment, especially together with hydraulic assisting or aeration. In fact, this author refers it to higher (than in Lake Ełk were presented) concentrations of nutrients and organic matter. This method is also far less effective, because phosphates are bound in enzymatic processes only periodically and then, after the death of algae cells, they are released into the water and re-enter the circulation of matter in the lake (Szlauer, Świerczyńska 1988, Szlauer, Szlauer 1999, Lewicki 2005). The results showed modest effectiveness of structures in the improvement of water quality. The only factor which values decreased after the flowing the water through BIO-HYDRO structure was chlorophyll a. While the amount of this component was similar on both sides of the structure during the spring, in summer and autumn it showed a clear decrease. However, this was not confirmed in the case of other parameters.

Water trophic state in the northern part of the lake basing on TSI is shown in Table 3. The partial TSI (SD) and TSI (TP) in the first years of the study (1998-2003) were typical of eutrophy, in next years of mesotrophy, however TSI (Chl a) and TSI (TN) all the time ranged characteristic value of mesotrophy. There was a slight improvement in the Secchi disc visibility of 0.8-1.3 $\mathrm{m}$ in the period $1999-2003$ to $1.8 \mathrm{~m}$ in 2007 and

Table 2. Changes of chosen chemical parameters using BIO-HYDRO structure in Lake Ełk (authors on the basis of the information in according to Wielgat 2009).

\begin{tabular}{|c|c|c|c|c|c|c|c|}
\hline \multirow{2}{*}{ Parameter } & \multirow{2}{*}{ Unit } & \multicolumn{3}{|c|}{ In front of the structures } & \multicolumn{3}{|c|}{ Behind the structures } \\
\hline & & 7.05 .2006 & 6.08 .2006 & 12.10 .2006 & 7.05 .2006 & 6.08 .2006 & 12.10 .2006 \\
\hline $\mathrm{PO}_{4}$ & $\mu \mathrm{g} \mathrm{P} \mathrm{dm}{ }^{-3}$ & 86 & 2 & 1 & 29 & 9 & n.d. \\
\hline $\mathrm{TP}$ & $\mu \mathrm{g} \mathrm{Pdm}^{-3}$ & 127 & 34 & 34 & 48 & 74 & 31 \\
\hline $\mathrm{N}-\mathrm{NO}_{3}$ & $\mathrm{mg} \mathrm{dm}^{-3}$ & 0.15 & 0.06 & 0.07 & 0.18 & 0.06 & 0.06 \\
\hline $\mathrm{TN}$ & $\mathrm{mg} \mathrm{dm} \mathrm{m}^{-3}$ & 2.28 & 0.87 & 0.64 & 2.05 & 0.86 & 0.74 \\
\hline Chl a & $\mu \mathrm{g} \mathrm{dm}{ }^{-3}$ & 8.89 & 34.17 & 47.74 & 9.36 & 18.35 & 33.58 \\
\hline Conductivity & $\mu S \mathrm{~cm}^{-1}$ & 398 & 315 & 358 & 396 & 319 & 360 \\
\hline
\end{tabular}

n.d. - no data. 
Table 3. Partial TSI during and after Lake Ełk renovation (in northern part of the reservoir).

\begin{tabular}{|c|c|c|c|c|}
\hline \multirow{2}{*}{ Year } & TSI(SD) & TSI(CHL) & TSI(TN) & TSI(TP) \\
\cline { 2 - 5 } & $60-14.41 \ln (\mathrm{SD})$ & $9.81 \ln (\mathrm{CHL})+30.6$ & $54.45+14.43 \ln (\mathrm{TN})$ & $14.42 \ln (\mathrm{TP})+4.15$ \\
\hline 1998 & 61.5 & 60.9 & 55.8 & .d. \\
\hline 1999 & 61.5 & 51.5 & 44.4 & n.d. \\
\hline 2000 & 60.0 & 63.2 & 58.2 & 63.2 \\
\hline 2001 & 60.0 & 53.2 & 58.2 & n.d. \\
\hline 2002 & 56.2 & 43.2 & 49.3 & 60.0 \\
\hline 2003 & 58.7 & 34.9 & 60.0 & 57.3 \\
\hline 2004 & 60.0 & 51.5 & 58.2 & 57.3 \\
\hline 2005 & 63.2 & 57.2 & 51.2 & 63.2 \\
\hline 2006 & 63.2 & $5 ., 8$ & 44.4 & 61.9 \\
\hline 2007 & 51.5 & 52.1 & 61.9 & 53.2 \\
\hline 2008 & 55.2 & 55.8 & 51.2 & 55.0 \\
\hline 2011 & 51.5 & 52.3 & 59.9 & 62.2 \\
\hline 2015 & 58.7 & 60.0 & 55.8 & 63.2 \\
\hline 2016 & 60.0 & 58.9 & 51.2 & \\
\hline
\end{tabular}

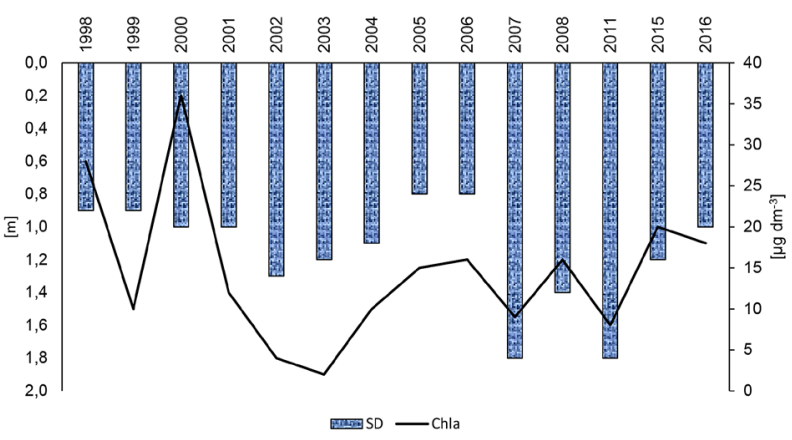

Fig. 3. Changes of transparency (SD) and chlorophyll a (chl a) concentration in the waters of northern part of Lake Ełk (Lossow and Gawrońska 1992, Wielgat

2009, Regional Inspectorate for Environmental Protection 2012, authors: 2015-2016).

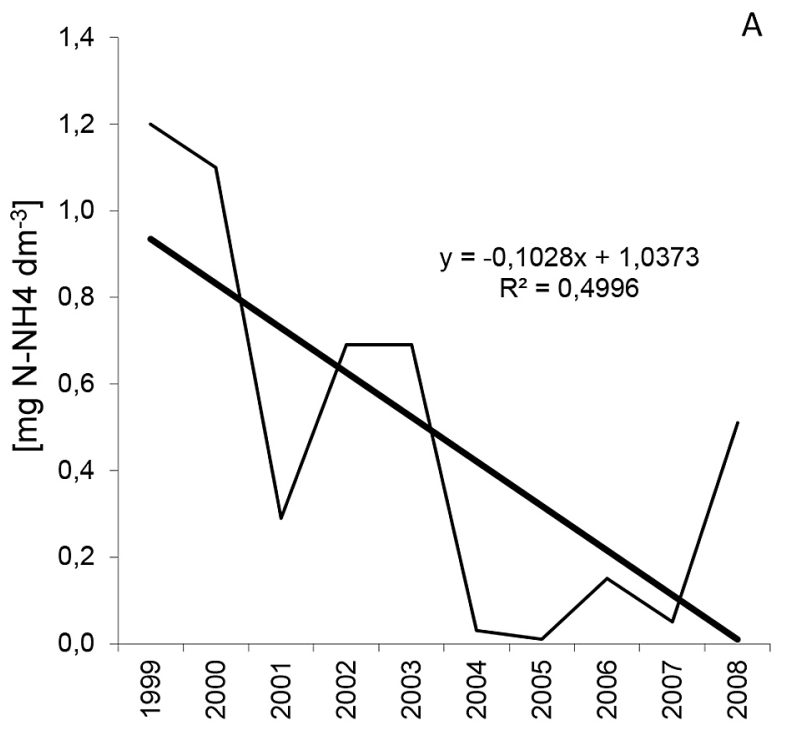

2011. In last vegetation periods SD decreased to the values noticed earlier $(1.2-1.0 \mathrm{~m})$. It did not correspond to a change of chlorophyll a concentration (Fig. 3). Initially, since 2000, this parameter value was decrease, reaching the lowest value $\left(2 \mu \mathrm{g} \mathrm{dm}^{-3}\right)$ in 2003. In the next years increasing trend was observed, reaching values of 20 and 18 $\mu \mathrm{g} \mathrm{dm}{ }^{-3}$ in $2015-2016$ years.

The dependencies between particular TSI values: TSI $(\mathrm{TN})>$ TSI $(\mathrm{TP})>$ TSI $(\mathrm{SD})=\mathrm{TSI}(\mathrm{Chl} \mathrm{a})$ suggest that the transparency of the water may be caused by high concentration of dissolved organic matter (Kratzer, Brezonik 1981, Brown, Simpson 2001). Probably, phytoplankton in some measure

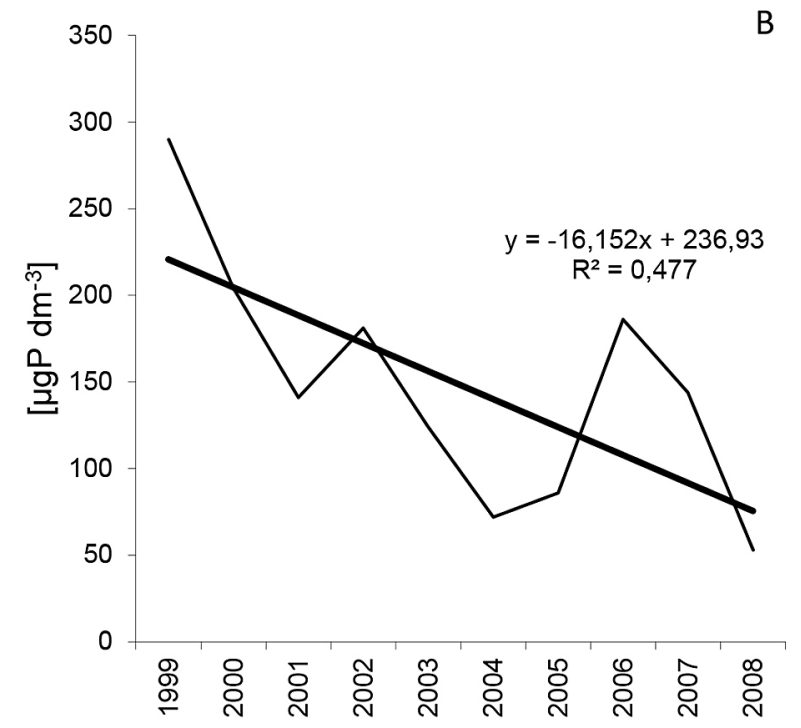

Fig. 4. Changes of TN (a) and TP (b) concentrations in the hypolimnion of northern part of Lake Ełk (Lossow and Gawrońska 1992, Wielgat 2009, Regional Inspectorate for Environmental Protection 2012). 
affected the water transparency, although might be limited by many factors, such as, limitation by nitrogen, zooplankton feeding, or toxic compounds. In 2011 year Regional Inspectorate for Environmental Protection (WIOŚ 2012) assessed the state of the chemical and ecological Lake Ełk as good.

It should be noted that the lake restoration brought only a temporary positive effect. Internal loading was inhibited by improving the oxygenation of the deep part of water (2003-2006). The decrease of the phosphorus content in the hypolimnion of the lake was permanent (Fig. 4 B) and it contributed to reduce the pool of phosphorus being in circulation and available in primary production. The level of ammonium nitrogen decreased (Fig. 4 A). Its presence in the hypolimnion indicates on return of anaerobic conditions (Grochowska and Gawrońska 2004), what is confirmed by the latest researches in 2015-2016 (values 0.6 and $0.7 \mathrm{mg} \mathrm{dm}^{-3}$ ).

In practice it was abandoned the concept drawn by Lossow and Gawrońska (1992), who proposed to carry out the aeration of water with the full destratification. Also in distribution BIOHYDRO structures it was not applied to the project which provided for setting them in 3 rows. In addition, the necessary conservation measures in the catchment were not done correctly. As a result ones have not achieved a satisfactory result of the treatment.

\section{Development of surrounding area}

At the same time the lake renovation as well as development of shores and surrounding area was going on. Actually, in the northern part of lake there is a swimming pool, the beach (which is also a place for cultural events) is located by the shore in the middle of the lake. At the south-eastern part of lake shore runs $6 \mathrm{~km}$-long promenade with pedestrian and bicycle path and this is well suited for recreational purposes. At the promenade there are two main points of rental equipment (kayaks and pedal boats) enabling recreation on the lake. The promenade is equipped with tables, benches and bike racks, allowing tourists and local inhabitants resting on the shore of the lake. According to the definition of lake tourism (Hall, Härkönen 2006) it takes place also in the areas surrounding the lake: there are tennis courts right on the beach and a camping site, very popular among young people visiting Ełk. The Center for Environmental Education is situated at the middle section of the promenade, right on the shore of the lake. The water fountain (illuminated at night) is located in the north-eastern section of the reservoir. The wooden sculptures of Polish kings and historical, illuminated at night bridge on the lake, behind which there are the ruins of the Teutonic castle of the fifteenth century, are also interesting. Another advantage is a well-organized base of catering and accommodation.

\section{Conclusions}

It should be noticed that the aspect of lake tourism development in Ełk is a priority, as it evidenced by the development of infrastructure related to recreation and active leisure. The presence of the monuments, sculptures and works of art are also very important. Considering the importance of the lake in an urban landscape, the role it can play with its development and the fact that the use of it is a form of anthropopressure, realistic tool to maintain the lake in a good condition is a local policy. It establishes different forms of lake protection and where appropriate - renovation. For this purpose, in the end of 90s of the last century, the Ełk city authorities decided to carry out the restoration of the lake.

They haven't followed strictly to the conception of Lossow and Gawrońska (1992), both in the way of aeration method and the distribution of BIO HYDRO structures. The achieved result of water quality was only periodic and slight (reducing the amount circulating nutrients in the lake, decreasing of trophy and algal blooms and improving visibility). Lake Ełk renovation was coordinated with the activities consisting in improving the aesthetic and development of the surrounding area of the lake, creating attractive places which were conducive to recreation and relaxation for tourists and locals. It should be emphasized that such activities should always be coherent, because they bring a measurable effect of improving the attractiveness and quality of life in the city and improving the tourist values. 


\section{Acknowledgment}

We wanted to thank the reviewers for their helpful advice and instructions. We also thank Mrs. Katarzyna Ewelina Karanowska for prior reconnaissance of the sites.

This study was supported by grant No 5280807-0806 from the Ministry of Science and Higher Education (Poland).

\section{References}

Bańkowska A., 2008. Efekty rekultywacji Jeziora Ełckiego metodą sztucznego napowietrzania i chemicznej dezaktywacji fosforu. Zeszyty Problemowe Postępów Nauk Rolniczych 532: 21-28.

Bartosiewicz A., 1998. Urządzanie terenów zieleni. WSiP, Warszawa.

Birch S.T., McCaskie J., 1999. Shallow urban lakes: a challenge for lake management. Hydrobiologia 395: 365-378. DOI: 10.1023/A:1017099030774.

Britton L.J., Averett R.C., Ferreira R. F., 1975. An introduction to the processes, problems, and management of urban lakes. Water in the Urban Environment. U.S. Geological Survey Circular 601-K.

Brown T., Simpson J., 2001. Managing phosphorus inputs to urban lakes. I: Determining the Trophic State of Your Lake. Water Protection Technique 3(4): 771-781.

Carlson R.E., 1977. A trophic state index for lakes. Limnology and Oceanography 22(2): 361-369. DOI: 10.4319/ lo.1977.22.2.0361.

Codd G.A., 1995. Cyanobacterial toxins: occurrence, properties and biological significance. Water Science and Technology 32(4): 149-156. DOI: 10.1016/0273-1223(95)00692-3.

Cosgrove I., Jackson R., 2015. The geography of recreation and leisure. Routledge, London (http://www.bookdepository.com/publishers/Taylor-Francis-Ebooks; accessed: 25 July 2016).

Curtis J.A., 2003. Demand for water-based leisure activity. Journal of Environmental Planning and Management 46(1): 65-77. DOI: 10.1080/713676706.

David L., Nagy Z., Gergely S., 2007. New Vasarhelyi Plan - reservoirs for tourism along River Tisza in Hungary. In: Nemeth A., David L. (eds), Handbook of lakes and reservoirs. A sustainable vision of tourism. Karoly Robert College, Gyöngyös: 34-41.

Duda-Gromada K., 2009. Turystyka jeziorna - nowa forma turystyki? Prace i Studia Geograficzne 42: 89-101.

Geoportal, 2016. Geoportal 2 (http://maps.geoportal.gov. $\mathrm{pl} /)$.

Giercuszkiewicz-Bajtlik M., 1990. Prognozowanie zmian jakości wód stojacych. Instytut Ochrony Środowiska, Warszawa.

Grochowska, J., Gawrońska H., 2004. Restoration effectiveness of a degraded lake using multi-year artificial aeration. Polish Journal of Environmental Studies 13(6): 671-681.

Hall C.M., Härkönen T., 2006. Lake tourism: an introduction to lacustrine tourism systems In: Hall C.M., Härkönen T. (eds), Lake tourism. An integrated approach to lacustrine tourism systems. Aspect of tourism 32. Channel View Publications, Clevedon, Buffalo, Toronto: 3-26.
Hermanowicz W., Dojlido J., Dożańska, Koziorowski B., 1999. Fizyczno-chemiczne badania wody i ścieków. Arkady, Warszawa.

Jańczak J., 1999. Atlas jezior Polski. T. III. Instytut Meteorologii i Gospodarki Wodnej. Bogucki Wydawnictwo Naukowe, Poznań.

Kistowski M., 1996. Wpływ struktury środowiska przyrodniczego zlewni na stan czystości jezior (na przykładzie wybranych zlewni i jezior Pojezierza Suwalskiego i Równiny Augustowskiej). Rocznik Fizycznogeograficzny. Uniwersytet Gdański 1: 53-87.

Kratzer C.R., Brezonik P.L., 1981. A Carlson - type trophic state index for nitrogen in Florida lakes. JAWRA Journal of the American Water Resources Association 17(4): 713-715d. DOI: 10.1111/j.1752-1688.1981.tb01282.

Kudelska D., Cydzik D., Soszka H., 1992. Wytyczne monitoringu podstawowego jezior. Państwowa Inspekcja Ochrony Środowiska, Warszawa

Kuś W.M., Sołtysiak J., Stecińska-Majkowska E., Wyszogrodzki P., 1981. Czas wolny, rekreacja i zdrowie. Wydawnictwo IWZZ, Warszawa.

Kwilecki K., 2011. Rozważania o czasie wolnym. Górnośląska Wyższa Szkoła Handlowa im. Wojciecha Korfantego, Katowice.

Łągiewka W., 1994. Zastosowanie biostruktur do oczyszczania wód powierzchniowych i ścieków. Ochrona Środowiska 3-4(54-55): 49-52.

Lewicki K., 2005. Porównanie efektywności metody chemicznej i biologicznej w obniżaniu trofii jeziora - eksperymenty "in situ". MS, Uniwersytet Warmińsko-Mazurski, Olsztyn.

Lossow K., 1997. Odnowa jezior. Ekoprofit 5(10): 11-15.

Lossow K., Gawrońska H., 1992. Koncepcja rekultywacji jeziora Etckiego. MS, Akademia Rolniczo-Techniczna, Olsztyn.

Martinez-Arroyo A., Jàuregui E., 2000. On the environmental role of urban lakes in Mexico City. Urban Ecosystems 4: 145-166. DOI: 10.1023/A:1011355110475.

Naselli-Flores L., Barone R., Chorus I., Kurmayer R., 2007. Toxic cyanobacterial blooms in reservoirs under a semiarid Mediterranean climate: the magnification of a problem. Environmental Toxicology 22(4): 399-404. DOI: $10.1002 /$ tox. 20268.

Romanowska-Duda Z., Mankiewicz J., Tarczyńska M., Walter Z., Zalewski M., 2002. The effect of toxic cyanobacteria (blue-green algae) on water plants and animal cells. Polish Journal of Environmental Studies 11(5): 561-566.

Schueler T., Simpson J., 2001. Why urban lakes are different? Water Protection Technique 3(4): 747-750.

Szlauer L., Świerczyńska I. 1988. Rola spełniana przez sztuczne podłoże umieszczone w zanieczyszczonym strumieniu. Zeszyty Naukowe Akademii Rolniczej w Szczecinie 133: 39-47.

Szlauer L., Szlauer B., 1999. Periphyton community on polyethylene sheets after the few years of exposure in a lake. Polish Archives of Hydrobiology 46(3-4): 339-344.

Tandyrak R., Gołaś I., Parszuto K., Bowszys M., Szymański D., Harnisz M., Brudniak A., Wysocka I., 2016. The effect of lake restoration by the hypolimnetic withdrawal method on the intensity of ambient odour. DOI: http:/ / dx.doi.org/10.4081/jlimnol.2016.1400.

Tandyrak R., Łopata M., Grochowska J., 2015. Rekultywacja jezior miejskich $\mathrm{w}$ aspekcie ich przydatności rekreacyjnej. In: Durydiwka M., Duda-Gromada K. (eds), Przestrzeń w turystyce. Znaczenie i wykorzystanie. Uniwersytet Warszawski, Warszawa: 515-524. 
Tuszyńska L., 2006. Edukacja ekologiczna dla nauczycieli i studentów. Wyższa Szkoła Pedagogiczna TWP w Warszawie, Warszawa.

Vollenweider R.A., 1976. Advances in defining critical loading level for phosphorus in lake eutrophication. Memorie dell'Instuto Italiano Hydrobiologia 33: 53-83.

Wielgat Z., 2009. Rekultywacja Jeziora Ełckiego. MS, Wszechnica Mazurska, Olecku.

WIOŚ [Wojewódzki Inspektorat Ochrony Środowiska w Olsztynie], 2012. Raport o stanie środowiska województwa warmińsko-mazurskiego w 2011 roku. Bibli- oteka Monitoringu Środowiska, Olsztyn (http://wios. olsztyn.pl/index.php?option=com_content\&view $=$ article\&id $=305 \% 3$ Araport-o-stanie-rodowiska-wojewodztwa-warmisko-mazurskiego-w-2010-roku\&Itemid=135; accessed: 11 December 2012).

Yamamoto K., Nakamura M., 2004. An examination of land use controls in the Lake Biwa watershed from the perspective of environmental conservation and management. Lakes $\mathcal{E}$ Reservoirs: Research $\mathcal{E}$ Management 9(3-4): 217-228. DOI: 10.1111/j.1440-1770.2004.00251.x. 